\title{
To exhibit or be exhibited: the visual art of Vetkat Regopstaan Boesman Kruiper
}

\author{
Nyasha Mboti
}

\begin{abstract}
This article examines the visual art of the late San 'Bushman' artist Vetkat Regopstaan Kruiper. The significance of Kruiper's artistic work is explored in order to call into question two problematic assumptions: first, that visual art amongst the San ended with rock art, turning the 'Bushman' artist into a vanished specimen, and, second, that what is found amongst the San today is not, strictly speaking, art. Anchoring these assumptions is the pigeonholing of 'Bushmen' as objects to be gazed at. Taking its theoretical departure from Lee and Hitchcock's call for an 'expanded anthropology', the article views Vetkat's art as both an act of authoring citizenship and belonging in contemporary South Africa, and as a form of exhibition-resisting exhibition.
\end{abstract}

Keywords: glass case effect, $\neq$ Khomani San Bushman, Vetkat Kruiper, visual art

\section{Introduction}

It is not often that one sees or hears minoritised subjects such as the San representing themselves to themselves, or to the world, on their own terms. Rather, they are talked about and represented both by their supporters and detractors. They are the exhibited rather than exhibitors. The conference that resulted in this special issue is a case in point. Though the gathering was made up of intellectuals largely sympathetic to the San, not a single 'Bushman' was present to give his/her side of the story. The absence may have been due to logistical or other issues, but it tended to underline the fact that the 'Bushmen' remain the told and the talked about.

This article was presented as a paper while Nyasha Mboti was a post-doctoral fellow at the Centre for Communication, Media and Society, University of KwaZulu-Natal.Nyasha.mbotigmail.com

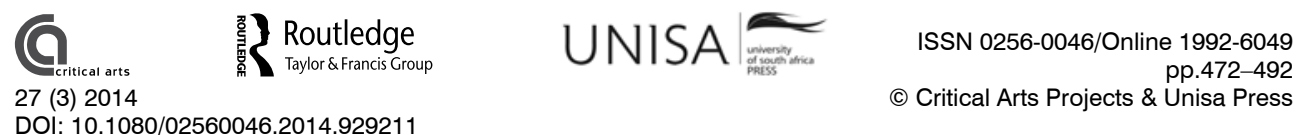


The tellers of San stories remain mainly white intellectuals, and the telling continues to happen with or without the San people's presence. It is as if these 'small relic people' (Lee and De Vore 1976: xvi) were never necessary to their own discourse and to discourses about them. An infamous instance of this specific 'they-are-notthemselves-needed' discourse is the so-called 'Great Kalahari debate' (Hitchcock 1985; Lee and De Vore 1976; Lewis-Williams and Biesele 1978; Wilmsen 1989). The debate was not 'great' because the San called it great. Rather, it was a great debate because two rival groups of white intellectuals chose to pitch their theoretical camps in an imaginary Kalahari. The Kalahari of the debate was imaginary in the sense that the debate largely took place in the minds of the interlocutors. It was not a debate in which Bushmen themselves debated about their origins and identities.

Why are Bushman thinking and presence in debates about the Bushman seemingly unthinkable? An historical aporia, with its roots in colonial cultures and imperial forgetfulness, seems to prevent Bushmen from being seen as thinkers, artists, philosophers and knowers. Lee and Hitchcock (2001: 273), in calling for an 'expanded anthropology', rightly celebrate the fact that 'perhaps the most significant development of the last two decades has been indigenous peoples speaking to us in their own voices'. This is an extremely important point. But why should this 'significant development' be reduced to a question of them speaking to $u s$ ? Which group is encompassed by the term 'us'? Why do we assume that their voice should be used to speak to us? Who are we to be spoken to? None of the issues should be about 'us' at all. The prevalence of 'us' in the discourse about Bushmen exemplifies what this articles refers to as the 'glass case' problem within which Bushmen continue to be exhibited - even by those who appear to fight in the Bushmen's 'corner'.

The 'Bushman' historically has been located in the place of the exhibition. When Clicko (real name Franz Taibosh), the so-called 'wild dancing Bushman' (Parsons 2009) died in 1940, the New York Times referred to him as 'the only African bushman ever exhibited in this country'. It appears that the only top billing Bushmen and other 'exotics' could be expected to achieve was via the trope of exhibition, as objects being displayed, enjoyed, fought over, fought for, fought against, used or pitied. From $19^{\text {th }}$-century colonial exhibitions, to Clicko, to The Gods Must be Crazy (1980), the Bushman has been constantly subjected to the traumas and absences of exhibition. The expectation that the Bushman is there to be had, as exhibition material, is what this article refers to as the glass-case effect. The glass case, a container housing exhibited objects, is a central feature of the macro-environments of museums and galleries. Its purpose in relation to the Bushman is its ability to fix, control and manage meanings centring on the Bushman's identity. The view that the Bushman artist has vanished, for instance, is possible only in the context of the historical surveillance and panoptical capabilities of the glass case. This article 


\section{Nyasha Mboti}

explores Vetkat's (2014) work in terms of resistance to the glass case, with his visual art being regarded as refracting and critiquing the notions of display and container.

\section{A people (and an art) presumed extinct}

The display and the container are core motifs in a discourse that, wittingly or unwittingly, reduces the San (and the Khoekhoe, among others) to a people presumed extinct. Many writers and scholars, some of them bestselling authors, have suggested that the San are extinct. Alistair Sparks (1997: 12), for instance, claims that there are no San people alive in South Africa today. The same assertion about San extinction is made by Laurens van der Post in The lost world of the Kalahari $(<1958><1977$ ? $>)$. As one of the first accounts to introduce the (myth of) San to Westerners, ${ }^{1}$ The lost world of the Kalahari is significant for its myths, the most important of which, as directly implied in the book's title, is that the Kalahari culture of the San represents a lost world. ${ }^{2}$ One question that could be asked of Van der Post's thesis is: lost to whom?

The racist marking of the San as belonging to a 'lost world' puts them on the same zoological scale as dinosaurs. ${ }^{3}$ As the self-designated last eye-witness of the lost world, Van der Post imagined that he had (re)discovered the lost San in the same way that the fictional Professor Challenger discovered dinosaurs in Venezuela in Arthur Conan Doyle's The lost world (1912). In fact, there has never been a point in the history of the San when they needed to be discovered or rediscovered. The San, like other Africans, have always been conscious actors in history, and have never been 'lost'. ${ }^{4}$ The myth of lost worlds, expressing the notions of pre-history and irretrievable loss, is itself hinged on displays and containers that have the supposed ability to arrest loss and disintegration.

The myth of discovery, as such, was entirely colonial in origin, in the same way that David Livingstone's discovery of Mosioa Tunya or Robert Fagg's discovery of the so-called Nok culture (Fagg and Plass 1964) were patent colonial myths. Linked to the discovery of the San was the fiction that they were remnants of the Stone Age, and that Van der Post had located the 'last bushman'. This myth dehumanised living Bushmen by suggesting they were a 'vanishing people', soon to be extinct. The myth fed patronising gestures (see Gordon 1985) aimed at the 'conservation' (see Miller [1993] and Kent [1996]) of the Bushman. ${ }^{5}$ Ed Wilmsen (1995), Gordon (1993) and a few others have, however, largely debunked the Van der Post-style romanticisation of the San.

The 'discourse on the extinction of primitive races' (Brantlinger 2003) extends to some commentators who sympathise with the cause of the San, with many of them still subscribing to the view that the San 'perished' or, at least, were destined to do so. For instance, Nigel Penn (1996: 83), in discussing the 'destruction of the Cape San', appears to conclude that the San 'perished' through no fault of their own. 
Robert Thornton (1983), Saul Dubow (1995) and Albert Moran (2009) suggest that well-known archivist of /Xam oral material, Wilhelm Bleek, also viewed Bushmen as a race destined for extinction. Despite his vastly cited /Xam collection, Bleek was a pioneer of the 'discourse of dying races' (Thornton 1983). Former South African president, Thabo Mbeki (in Barnard 2004: 10) - the political figure who presided over the return of parts of $\neq$ Khomani land in the Northern Cape - is also on record as describing the /Xam as a people who 'have perished and even ceased to exist'. Patricia Vinnicombe (1976) makes reference to 'the last' Bushmen of the MalotiDrakensberg mountains.

\section{The glass case effect}

The glass case effect occurs when the object of an exhibition is locked away behind safety glass for purposes of preservation, storage, and, most importantly, display. Glass cases are made to order for artworks, specimens, collectibles, trophies and memorabilia. They are airtight, sealed and climate-controlled. They represent an environment where things can be displayed and, by being displayed, disciplined. This metaphor arises out of my previous work for the National Art Gallery in Zimbabwe, where I assisted with visual art education, curation and preservation. It is during this tenure that I became aware of how the display case interacts with, and shapes, art objects. Display cases are special visual and semiotic objects in their own right, in addition to being permanent and important fixtures of museums and galleries.

The glass case incorporates several features, such as a sturdy wooden pedestal and locks to keep the contents safe. The case may also come with wheels to enable movement from site to site within the protected and protective walls of the exhibition space. Because objects that belong in a glass case are sensitive to damage, the art gallery and the museum are designed to be inert internal dust-proof environments, with minimal sunlight and air circulation. Within the silent and isolated microenvironment of the glass case, climate, humidity and temperature are carefully monitored and managed. All objects meant for display have a display lifespan, and the glass is meant to prolong the life of the displayed object. In this way the object continues to be available to paying or invited audiences for as long as possible.

Easily the most important feature of the display case is the glass; often tempered and shatter-resistant, it is the feature that invites the voyeuristic gaze. It is transparent so that whatever is being exhibited is available to the panoptical gaze of the viewer. Whether wall-mounted, table-display, freestanding, hanging-from-the-ceiling or custom-made, all glass cases are containers. This is an important feature. As containers, they function to contain in the sense not only of keeping inside and having within, but also holding back, limiting and regulating. A contained thing is simultaneously lessened, fetishised and objectified. This is due to the fact that the 


\section{Nyasha Mboti}

contained object takes the shape of its container, or, at the very least, exists within its limits.

Displayed things are preserved in tempered safety glass not only so that they are available to be seen, but also because of the objects' permanent and perpetual inertness, fragility and assumed defencelessness. Displayed objects are protected from fading, damage, embrittlement, corrosion, shrinking, accretions, discolouration, dust and deterioration, because they cannot protect themselves. Yet, they have no control over the way in which they are positioned as items in the glass case. Rather, the curator, collector, seller or museum director chooses how the objects should be placed in order to obtain the maximum exhibition effect.

The glass case belongs within the macro-

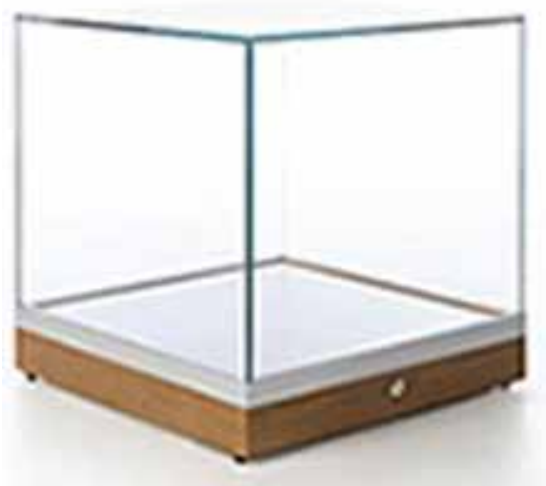
environment of display and exhibition, i.e., the entire display area. The exhibited objects, however, belong only within the microenvironment of the display case - an enclosed space which, from one point of view, represents arrested movement and arrested history. This sense and reality of arrest or fossilisation is at the heart of so-called conservation. It is a fixation in place and time, and retains power in the hands of the arrestor. Objects that retain both movement and history are ill-suited for the macro-environment of the museum and the micro-environment of the vitrine. To

have movement and history is to cease to be an object. It is, rather, to expand into a doing and speaking subject. Exhibition is hence a form of prevention, in that it prevents both doing and speaking, and is a careful replacing of the subject with an unprotesting object or fetish.

The displayed object, which depends on the transparent glass for effect, is a fetish that draws its power from being gazed at. The displayed object pulls crowds and draws gazes towards it. However, the power of the fetish-object is always already limited: it is one-dimensional, dependent and accidental because the object cannot transcend the trauma-based isolation into which it has been condemned. The truth of this point is asserted in the Aesopian fable of the fox and the theatrical mask:

A Fox had by some means got into the store-room of a theatre. Suddenly he observed a face glaring down on him and began to be very frightened; but looking more closely he found it was only a Mask such as actors use to put over their face. 'Ah,' said the Fox, 'you look very fine; it is a pity you have not got any brains.' (Aesop n.d.: 23) 
The mask only has accidental power over the fox. As the fox observes, the object has no brains, no agency. Real power lies with the exhibitor, i.e., the one arranging the display and asserting his/her preferences for how and where to place the display. As Kent Brockman, the newsman in The Simpsons, says: 'There is an eclipse when I say there is an eclipse.' ${ }^{6}$ The power of the exhibition glass case is out-bound communication. It is, fairly and squarely, the power of vitrification. Exhibition works by ultra-saturating the micro-environment with isolation, and dispensing frames with which the displayed object is seen into the macro-environment.

This paradox of exhibition as frame-dispenser and echo chamber is observed in Pippa Skotnes' 'Miscast' exhibition. Despite in large part exposing the racist and dehumanising way in which the San were exhibited, 'Miscast' remained an exhibition which failed to free the San from the vitrine effect. In fact, it freed them from one set of exhibitions, only to lead them into another. The word 'exhibition' occurs 77 times in the 'Miscast' catalogue, where not once is it enclosed in quotes. The colonial exhibitions that degraded the San and the 'Miscast' exhibition which sought disrupt them both shared and used the same term to refer to what they were doing. 'Miscast' as an exhibition failed to draw attention to this anomalous relationship, and the word 'exhibition' retained all of its centuries-old privilege and traumaticinstitutional power over the San. 'Miscast' can thus be said to have failed to achieve its goals, because it was never going to be anything but an exhibition ${ }^{7}$ - it simply exchanged one kind of echo for another, and managed to leave everything as it had found it. The environment of the exhibition is always a manufacture of some sort specifically one within which it is impossible to exhibit as if one were not exhibiting. It is impossible to exhibit in such a way that the result is not an exhibition. What else is the glass case outfitted for?

\section{Vetkat Kruiper}

Born at Twee Rivieren, a rest camp in the then Kalahari Gemsbok Park on 1 April 1969, Vetkat was the youngest son of the late Ou Regopstaan Kruiper, the wellknown Kalahari $\neq$ Khomani leader. Vetkat died on 11 April 2007, aged 38. Vetkat had his 'studio' on a farm called Blinkwater, just outside the reserve now known as the Kgalagadi Transfrontier Park, where he lived with his poet wife, Belinda. Vetkat's works are in private collections at the Natal Museum Services, the McGregor Museum at Kimberley and the University of Pretoria. From 2002 to 2005 his art was displayed at the United Nations (UN) as part of an exhibition of indigenous art, while his 2004 tour of the United States of America culminated in his addressing the UN. Vetkat's visual art is remembered and celebrated in the first edition of Mooi loop, launched at the Bergtheil Museum in Durban in 2011. ${ }^{8}$ 


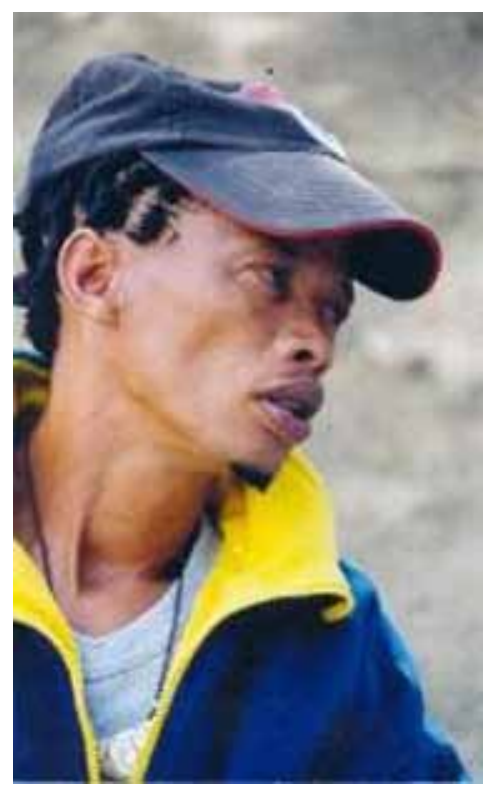

\section{'They make no rock art and have no tradition of rock art'}

Kalahari San rock engravings and rock paintings are regarded as an irretrievably lost culture. The Kalahari San artist is thought of as an absent and vanished museum specimen, hence:

A more visible part of the archaeology of the Bushmen, and one which more people know about, is the rock art found throughout the mountains of southern Africa. Initial attempts to understand these paintings were fraught with problems, because the painters had all died before anyone thought to try to find out why they had painted. (Smith, Malherbe and Guenther et al. 2000: 18, emphasis added)

The context of a people who had 'all died' continues to inform questions of dating and authorship. David Lewis-Williams and Thomas Dowson (1989: 4), for instance, ask '[w] ho were the artists?', noting that 'there was heated controversy over the identity of the artists'. Their conclusion is that

[t]oday remnants of the Bushmen survive only in the Kalahari Desert. Contrary to popular belief, these survivors are not descendants of the southern painters who were driven into inhospitable areas by more powerful peoples; they make no rock art and have no tradition of rock art. Some of them are aware of paintings in the Tsodilo hills, but, as Megan Biesele found, they say god put them there. The groups who lived farther to the south and made the art spoke different languages. They became extinct about a century ago as a result of white colonisation. (ibid: 11, emphasis added)

The conclusion is that artists such as Vetkat are not related in any sense to the rock artists who are said to have been extinct for a century. ${ }^{9}$ Rock art researchers generally note that 'there are no recorded interviews with the painters themselves', ${ }^{10}$ thus no one is around to shed light on the codes and meanings of the rock paintings. ${ }^{11}$

Lewis-Williams' 'shamanistic model' attains its framing power in the context of extinct artists. His commitment to refuting one form of exhibition - that the San were 'primitive people who had no sensitivity and certainly no spiritual experiences' (Lewis-Williams 2002: 143) - leads him to propose a more severe form of exhibition: Bushmen as shamanistic freaks. Lewis-Williams' generally accepted theory ${ }^{12}$ explains all Bushman art as having been inspired by 'altered states of consciousness'. He therefore constructs what he calls a 'shamanistic cosmos' composed of 'tiers' generated in these altered states (ibid: 145). ${ }^{13}$ 
Chimamanda Adichie (2010) succinctly warns of 'the dangers of the single story'. Lewis-Williams' oeuvre on San rock art, beginning in the late 1970s, has sought to assert 'how San cosmos and art are inseparable' (2002: 148), but what if they are separable? This imposition of inseparability is not only troubling for the way it denies the San agency, but also for the way it continues to glass-case Bushmen. Lewis-Williams, for instance, uses the words 'San' and 'shaman' interchangeably, arbitrarily sealing the two together. The so-called 'trance hypothesis', which seems to have been developed not from asking the Bushmen themselves what they thought and knew about their world, but more or less from hypothetical speculation, is in many ways an aspect of the glass-casing of Bushmen. This totalising of Bushmen into shamans through interpretations of rock art that allows only single readings is related to the present-day exhibiting of Bushmen.

The postulations of supposed vanishings and disappearances ${ }^{14}$ are resisted by Richard Lee and Bob Hitchcock (2001), who call for 'an expanded anthropology, by celebrating the birth of new ethnicities and not just mourning the passing of the old'. Part of this study of Vetkat Kruiper's art is a response to their call for an 'expanded anthropology' (ibid: 273).

\section{Vetkat's art}

\section{Titles}

Since Vetkat did not give any of his paintings titles, it is difficult to refer specifically to individual paintings. It is not possible to reference specific paintings by page number either, because the 2011 edition of Mooi loop has none. It is quite possible that Vetkat never intended his pieces to be separated and individualised. I have therefore distinguished the anonymous paintings simply by labelling them as Figures 1 to 8 . I photographed all the artworks used here, from the originals.

\section{Fragments}

One way of analysing Vetkat's visual art is to literally fragment and examine it piece by piece, as with a magnifying glass. This 'fragmentation method' is informed by the art itself. Vetkat often literally crams many fragments of representation onto a single A4 canvas (see Figures 3 and 8). I hence present some artworks as wholes and others as photographed fragments of wholes. This method of visual analysis shows both the detail and the several layers of meaning that Vetkat built into his pieces.

The three pieces in Figure 3 show the density of detail that the artist preferred. Several stories or bits of action co-exist in a single frame. The space around the other-worldly monochromatic swaggering figures is either occupied by free-form plants, huts, tunnels, snakes or flowers, or is simply left empty. The technique of 


\section{Nyasha Mboti}

layering objects horizontally, shown in the three panels in Figure 3, manifests in the majority of Vetkat's pieces. This 'layer motif' indicates the existence of repeatedly and densely overlapping worlds and planes of reality, giving unity to Vetkat's work. No parts are dominant or subordinate; rather, each fragment represents an authentic world. The human figures seem to be the primary focal point initially, but this perspective changes when one looks more closely at the hut, eland, snake or mantis. ${ }^{15}$

\section{Technique}

Vetkat's chosen technique is drawing, but he does more than just draw. Rather, he crosshatches and squirkles his 'canvases' with the tip of his pencil or brush. The

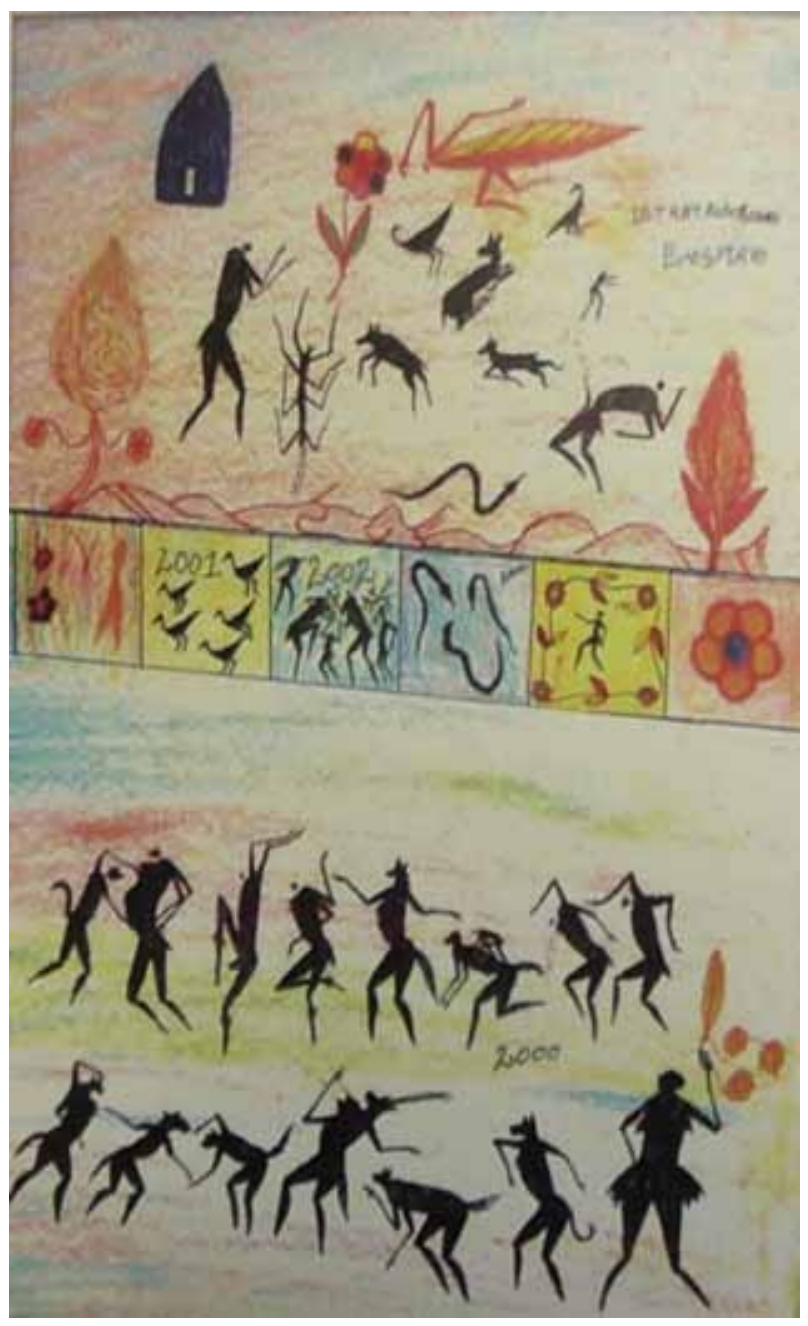

effect is that his line-drawn figures seem like kinetic gesture sketches (Figure 4). The three worlds divided by the red and black barbed wire fences are full of the life and activity of humans, therianthropes, animals, reptiles and birds. Even the trees appear to be gesturing to the side and towards the skies. The landscape is unfinished; each 'scene' appears to have an individual identity linked to the others through kinaesthetic, animated gestures. There is rarely a smooth finish. Rather, Vetkat continually mixes blunt short strokes, curved short strokes, dashed lines, and strange and familiar shapes. In drawing this way, Vetkat seems to have found the simplest and most efficient way to communicate visual ideas.

The pigment used in Vetkat's work is often very simple. Rock painters used red ochre (with some 

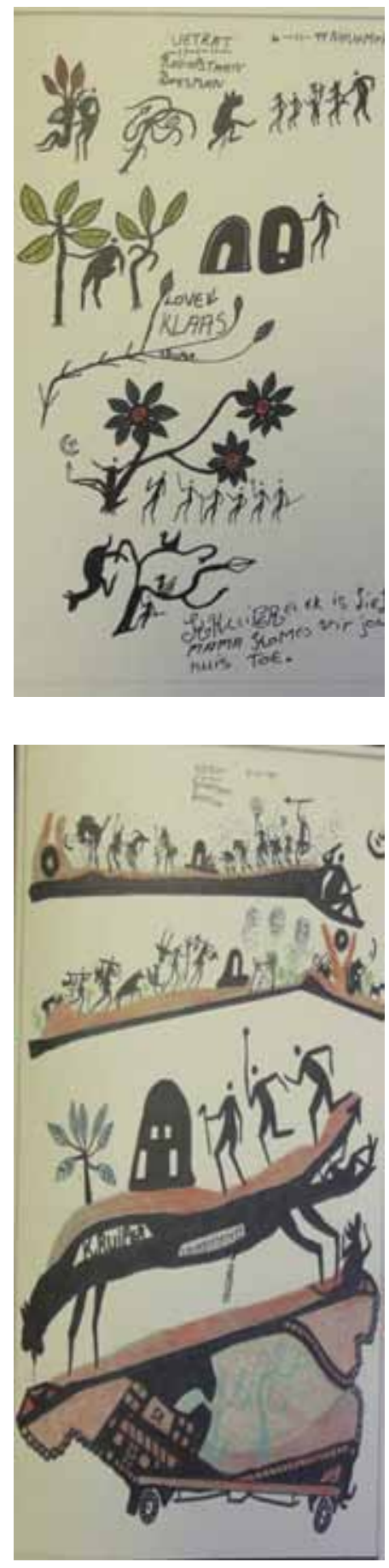

paintings in maroon, yellow, black and white pigments) to represent subjects ranging from animals (mainly eland) to humans, therianthropes and even ox-wagons and mounted men with rifles (LewisWilliams 1981). Vetkat also works with splashes of colour (Figures 3 and 4), as well as in monochrome and bichrome. Representations of humans and therianthropes, however, are mostly in monochrome. Many of the 'painted' objects in Mooi loop are monochrome images with the colour blocked in.

Vetkat brings together a number of varied techniques: fine-line paintings where he traces the outline of an image, filling the interior with lines of the same colour; tracing the outline in one colour, with the image filled in with another slightly different colour (Figure 6); two or three blocks of colour in the same image (Figure 5) sometimes creating strong contrasts; polychrome where he uses three or more colours in the same image; outlining the image with a single line; 'pecking' out in a chopping motion; inky scratching; shaded polychrome in which several colours blend to create depth effects and shading; large areas of colour and tone (Figure 5), and so on. Figure 5, for instance, shows the expressive use of brown and white inks. Partially wet media appear to have been used to create the flowing softness, transitions and organic quality of the flocks of birds. None of Vetkat's paintings seem to have been done with a finger or a very broad brush/applicator, suggesting an interest in detail. There are a few bold designs, although most are highly stylised, regardless of the subject matter. The style ranges from energetic to subtle (Figures 2 and 5).

Some paintings are plain, while others are furiously decorated with gestural strokes, down to the 'calligraphy' of Vetkat's signature and date. Some of Vetkat's artworks are 'engravings' on paper, characterised by careful detail in depicting plants and a delicate portrayal of emotion and postures. Regular patterns compete with asymmetrical patterns. This 


\section{Nyasha Mboti}

blending has more than a simple mimetic function; it also shows how Vetkat imagined his social world.

There is a personal touch to Vetkat's visuality that suggests innovation and originality. I observed that the 'chaos' in his paintings is actually unity - a result of his mastering a new technical harmony which the artists who engraved in the open on igneous rocks and painted in caves on granite, limestone, sandstone and quartzite did not (and perhaps could never) negotiate. The distribution of the two techniques of rock art (engravings and rock paintings) was largely governed by geology, with engravings associated with igneous rocks such as dolerite and occurring out in the open, while rock paintings were most common in areas where there are caves or rock shelters in outcrops of granite and in sedimentary rocks formations of limestone, sandstone and quartzite. Basically, it is rare, though not unknown, to find both rock paintings and engravings together at the same site. Vetkat seems to have found a way to blend and represent both engravings and rock paintings as composites, on the same canvases, thus doing away with the limitations that faced the Kalahari 'old masters'. His medium simultaneously allowed immediacy, ex/change and a sense of movement.

\section{Vetkat's polyptych}

The word 'polyptych', which comes from the Greek polu which means 'many' and ptyche for 'fold', refers to a painting that is separated into sections or panels. ${ }^{16}$ Polyptychs often display a 'main' panel (usually the largest) and several 'side' panels or 'wings' which can be varied to show different 'views' or 'openings' in the artwork. Vetkat's representation of several worlds-in-one in nearly all his paintings suggests he adopted a polyptych-style representation of Bushman social worlds. For instance, Figures 6 and 8 can easily be broken down into panels depicting various objects and happenings. Figure 6 shows animated human figures, eland, plants and huts in the central panel flanked by 30 other 'wings', all carrying various messages. The relationship between the centre and its margins is ambiguous. The side panels seem to strengthen the message of the central panels, while simultaneously retaining their own independent identities. The central panel itself is far from a unified whole, but rather contains several other fragments. There are even three panels with text in Afrikaans, showing the fluid interaction between the text and the visual. The central panel of Figure 6, in shaded polychrome, has its own centre depicting what seem to be translucent human beings bathed in light along with several other fragments. To see the amount of 'code' hidden and compressed in this polyptych, one might need to zoom into the artwork or use a magnifying glass.

Where the polyptych ordinarily refers to multi-panel paintings, Vetkat's polyptych style is a multi-world staging of encounters. Figure 8, for instance, can be divided into representations of sex, war, dancing, child's or horse-play, religious worship, 
celebration, quarrel, division, friendship and community. The viewer can choose to see this as a single or as many artworks. Vetkat's polyptych also facilitates transport and mobility, which rock art cannot do in its original locations. Finally, Vetkat's polyptych vision is not merely visual but also tactile, not only $2 \mathrm{D}$ but $3 \mathrm{D}$ and $4 \mathrm{D}$, stereoscopic rather than just monocular - an effect of weaving and interlacing objects and the use of perspective that allows the viewer to see many worlds unfolding at once.

\section{The placement of objects and choice of themes}

Vetkat's depictions are fragments of different impulses that are impossible to sew into a univocal whole. Nevertheless, the placement of objects in most of his pieces is seldom random. An example is the use of the understated symbols/features of the hut and the fence (Figure 6). The repeated placement of the hut suggests a conscious preoccupation with and celebration of 'home' and shelter. Incidentally, 'home' is a real and grounded need amongst the $¥$ Khomani-just as is the impulse to heal and be healed. Their history of dispossession, dispersal and displacement make the hut a powerful metaphor of return. The fence, on the other hand, underlies the division of private space (marked by 'trespassers will be prosecuted' signs), and Bushman space and desire paths in the Kalahari (Mboti, forthcoming). Whereas the hut gives a sense of place and celebrates Bushman 'rurality', the fence suggests division, alienation and the violence of 'modernisation'. In several of Vetkat's works, objects and things separated by fences are twisted and bent out of shape.
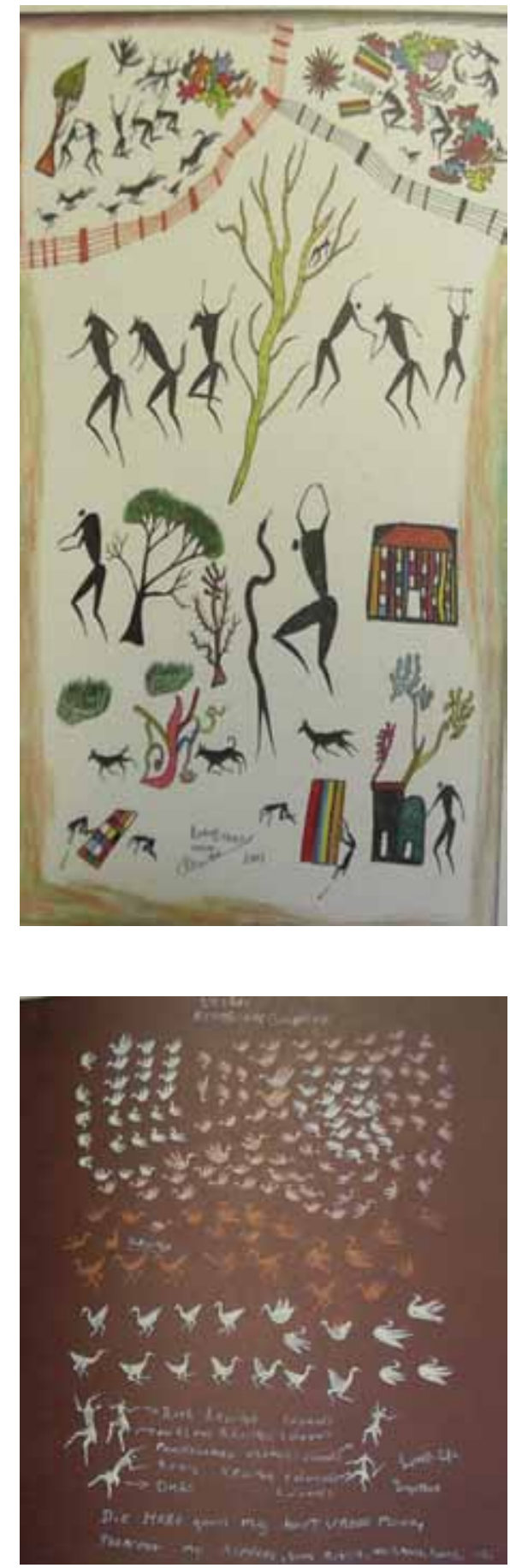


\section{Nyasha Mboti}

Vetkat has a seemingly inexhaustible store of images to draw from. Apart from the hut and the fence, he explores a range of other themes such as violence, love, modernity, change, beauty, nature, sex, humanity, music, work, fertility, nation, space(s), time, place, boundaries and silence(s). Ecology, movement, stasis, ex/ change and family are also a conscious preoccupation. ${ }^{17}$ Vetkat Kruiper's polyptych, layered vision does not limit itself to any specific expressive mode, nor is it limited by taboo topics.

\section{Interpretation ${ }^{18}$}

One possible definition of Vetkat's Kalahari visuality is to represent it as art brut or 'outsider-art', a 'rough' or 'unofficial' art that is defined as the work of artists who demonstrate little influence from the mainstream art world. Vetkat's oeuvre is certainly boundary-crossing, boundary-smashing and boundary-refusing. I do not believe, however, that Vetkat's art is really outsider art at all. The outside-ness of the Kalahari San as a people has been exaggerated, partly as a result of the romanticising myth of the ultra-remote lost/vanished world. In fact, I think of Vetkat's drawings as representing a thematic refutation of enforced outsideness. The discourse of art brut, possibly emancipatory, still returns us to the unproductive meme of primitive, idle doodlings or to the outside/inside that, pursued to its (il)logical conclusion, takes us back to apartheid. To define Vetkat's work as 'outsider art' is, in one sense, to falsely insist on the Kalahari San's separateness, especially at a time when no one has done
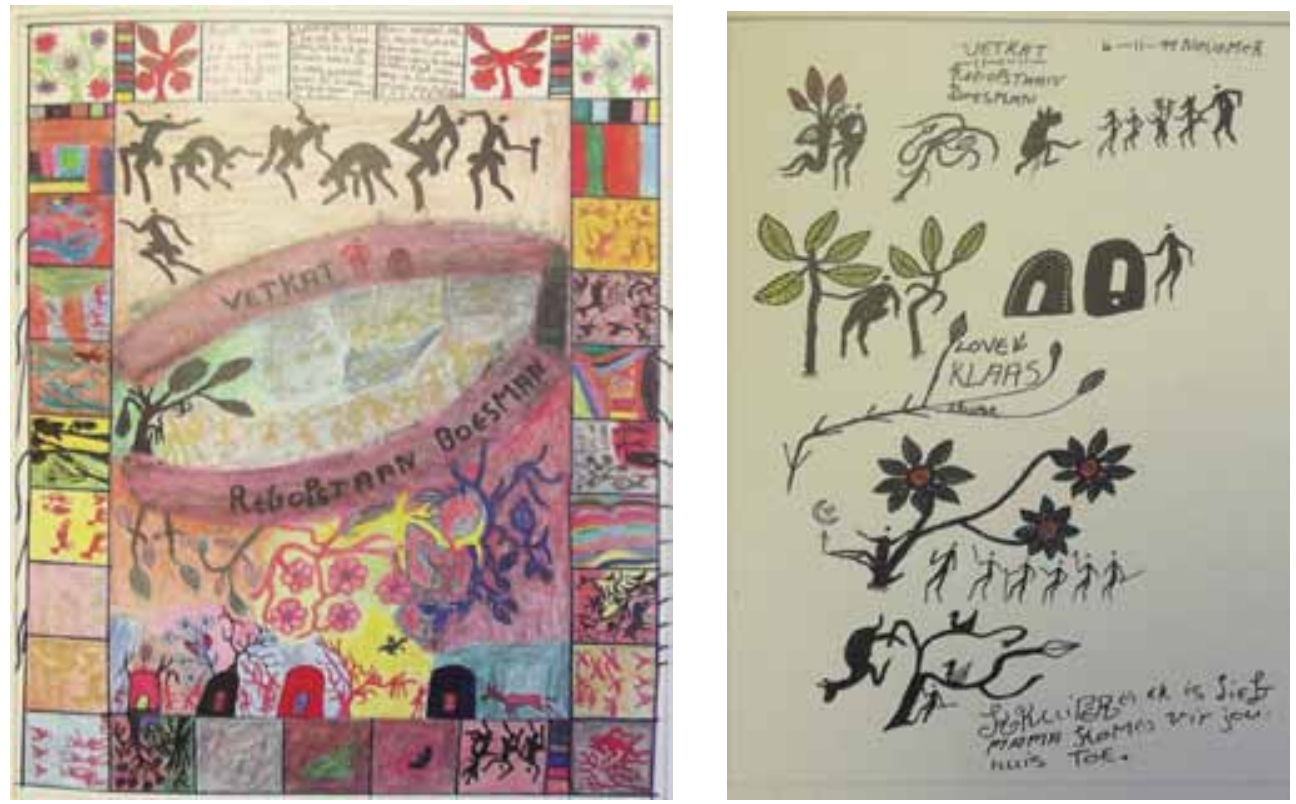
anything substantial to prepare the ground for a culturally sensitive understanding of the many histories that account for how the San came to be labelled as 'outside'. ${ }^{19}$ Ultimately, affirmation/refutation of outsideness can only be pronounced on the Kalahari's San's own terms, by the Kalahari San themselves.

Nhamo Mhiripiri (2008) defines Vetkat's art as postmodernist because of the artist's thematic focus on identity and 'sensitivity to moral ecology', his 'cryptic' style and polysemic meanings. Mhiripiri draws on notions of simulacra and hyperreality, as well as Jungian psychoanalysis, to strengthen this view. However, Vetkat's art fits postmodernism uneasily, as noted with the examples of the fence and the hut. Mhiripiri's latest intimations to me (2012) suggest that he has begun to question his earlier postmodernist-art thesis; he emphasised that Vetkat's visual art is best appreciated as intellectual production, with a conscious aesthetics and a sociopolitical awareness. It is not instinctive 'trance' art. It is never merely 'ethnic' art. I would go further to say Vetkat's work evidences not only intellectual production but also advances a future-solving intellectual proposition: to exhibit or to be exhibited.

To the extent that art is a part of the world from which it emerges, Vetkat's work is 'Kalahari style' in the sense of Kalahari visuality; to the extent that art is about other art, Vetkat's art is in conversation with rock art. In Mooi loop (2011), the first published collection of Vetkat's visual art, the history of Bushman visual art, previously separated generically as engraving/painting, re-emerges for the first time as a new $21^{\text {st }}$-century hybrid. The cave and the open site have been united powerfully in Vetkat's works, which hence symbolise e/mergence (emerging/merging). Most of the motifs used in his paintings show objects and characters emerging out of, and merging into, each other. Twenty years after the 'end' of apartheid in South Africa the so-called rainbow nation has not been able to make its colours merge into a humanising harmony. E/mergence is a complex cultural technique that Vetkat has already mastered.

Vetkat's work is a number of things simultaneously: a demonstration, a refutation and an affirmation, a breaking and a joining, and a movement within stasis. Part of the reason his work assumes these functions can be attributed to the existence of gaps and aporias that serve to structure collective memory (and forgetting) about the Bushman. Vetkat's visual art, in fact, has two clear cultural uses (though it is not limited to these): $\operatorname{ref}(\mathrm{m})$ utation and affirm(n)ation. What is refuted is the Cartesian mutilation (colonial and postcolonial) and collapsing of being-Bushman into beingexhibited. Mutilation (and its absences) is replaced by a radical and productive (trans)mutation and newness that Vetkat found possible in the silences and openness of Blinkwater and the Kalahari. What is affirmed is the voluntary citizenship of the Bushman in the modern nation of South Africa, born in 1994, with all the attendant curses, consequences, losses, gains, rights, obligations and responsibilities that citizenship entails. 


\section{Nyasha Mboti}

Refutation and affirmation are tied to the fact that identity cannot be forced. It is at once a birthright and a conscious choice. Vetkat's polyptych vision, a function of being grounded, refutes many incorrect notions about the Kalahari San: that they were and are outcasts and remnants of the Stone Age, that they were a child-like, vanishing/vanished people, or that rock visual art was a collection of naïve daubings by primitive doodlers. It replaces all these absences with citizenship. Above all, however, it affirms radical cultural ex/change: the ability to exhibit and not just be exhibited.

\section{Conclusion}

There is a lacuna, a hiatus of sorts, around the reality of being San. The hiatal reality is this: the 'Bushman', though living, is actually meant for the glass case. This fissure (really an absence) takes many forms which collectively play the same sort of role: to fissure and separate the Bushman from his reality, and to hyphenate his identity. $\mathrm{S} /$ he is not actual, but only a signification, a type. This article has explored the visual art of San 'Bushman' artist Vetkat 'Regopstaan' Kruiper and how it diffracts and refracts the glass case effect and represents a breaking out of the glass case. A factor in the glass display effect is the availability of a thing to be seen, looked at and gazed at. Vetkat's art resists availability. He does not paint simply to be displayed. Rather, he seems to deliberately retain an opaqueness, a density and a layeredness of visual style, symbolism and theme that frustrate expectations of transparent themes, patterns and motifs. His art is, in a sense, invitrifiable art. It actively resists the micro-climate of the glass case. It is neither dependent on glass, nor on what the glass-makers say.

\section{Notes}

1 Ironically, less than a quarter of the book is about the San, much of it is about Van der Post the desert explorer and 'last eye-witness', and the process and details of his expedition. Van der Post barely spent two weeks with the Bushmen.

2 The myth of 'lost worlds' goes back as far as 1912 with Conan Doyle's novel, The lost world, which describes a journey to the Amazon where dinosaurs and other extinct 'prehistoric' creatures are to be found. Other than dinosaurs, carnivorous plants and giant spiders, there are also cannibalistic natives to be found in this 'lost world'. Irwin Allen's The Lost World (1960) took the myth to the screen.

3 Though extinct, dinosaurs are re-made for display, for instance, in Stephen Spielberg's cinematic classics, Jurassic Park (1993) and The Lost World (1997).

4 As Mklós Szalay (1995) notes, the Bushmen did not become extinct at all. Rather, their history is replete with evidence of varieties of resistance against colonial expansion (Elphick 1977; Marks 1972; Wright 1971) as well as incorporation and absorption into farm labour populations, rural proletariat and the military (Marshall 1980; Szalay 1995; Volkman 
1985). In fact, the San have proven remarkably suited to surviving one existential threat after another (Guenther 1997, 1999; Hitchcock 1985; Lee and Hitchcock 2001; Tomaselli 2005).

5 It was also implied that there used to be untouched, truly-wild, authentic and 'real' Bushmen who are - unfortunately - gone forever. This untouched Bushman could do no wrong, was lovable, child-like, innocent and pure, and could only be corrupted by external influence. This myth, which is a corollary of the 'noble savage', is found at its starkest in cinematic form in Jamie Uys' popular 1981 film, The Gods must be Crazy, where the Bushmen have no law and are incapable of anger or crime. The untouched Bushmen - a symbol of 'the primitive in ourselves' according to Van der Post - were also the first inhabitants of South Africa, before being driven into the Kalahari by hostile blacks and whites.

6 The Simpsons S20/E13 'Gone Maggie Gone'.

7 For different perspectives on 'Miscast' see Skotnes (2002) and Jackson and Robins (1999).

8 Important pioneering questions in contemporary San art have been raised by Skotnes (1991, 1994), Guenther (1997, 2003), Barnabas (2010) and Mhiripiri (2010). Skotnes' (1994: 316) paper marks the first attempt in critical literature to depart from the 'previous insistence that the painting itself is unable to offer any information as to its meaning'.

9 The cultural meanings of this 'lost world' of the Kalahari are supposedly tucked away in ancient code, needing Rosetta stone-type code to allow decoding (Lewis-Williams 1981, 1984). The continued natural deterioration, as rock faces slowly crumble, of the petroglyphs and pictographs compounds the sense of irretrievable loss.

10 Bradshaw Foundation 'Cracking the code of San rock art' http://www. bradshawfoundation.com/bushman/san_bushmen_south_africa.php. Brentjies (1965: 1) refers to rock art as 'galleries of primeval art' which 'bear witness to otherwise forgotten centuries of African life'.

11 Ironically, it is not logical or expressly necessary to have Picasso's physical presence to sense the chaos of 'Guernica', Munch to feel the choking panic of 'Scream', or Van Gogh to sense the earthiness of 'The Potato Eaters'.

12 That Lewis-Williams' shaman model is widely accepted is clear, when even Mathias Guenther (1997: 121), whose pioneering study of contemporary Bushman art is among the soundest, refers to Qwaa Mangana as a 'shamanistically inclined artist'. The theory has not been uncontested, though (see, e.g., Solomon 1997, 2006, 2009).

13 Thanks to the important work of scholars such as Lewis-Williams $(1978,1981 \mathrm{a}$ and b, 1983a and b, 1984, 1989, 2002) and Megan Biesele (1978, 1993), it cannot now be denied that the San are not religious. However, the 'discovery' of San religiousness appears to have become a ready tool to subsume and explain everything to do with the San.

14 It has been asserted that ' $\mathrm{t}]$ he dating of rock art is perhaps the most important empirical issue' (Dowson and Lewis-Williams 1994: 5). The early concern with issues of dating and authorship in rock art research (cf. Beaumont and Morris 1990; Dowson 1988; Dowson and Lewis-Williams 1994; Lewis-Williams 1983; Morris 1988; Morris and Beaumont 1991; Schoonraad 1971; Steel 1988) reflects precisely the assumption that the rock artists may have vanished. This is illustrated, for instance, at the beginning of Eastwood and Eastwood's (2006) book about rock art where they state: 'We have set out to take you 


\section{Nyasha Mboti}

with us on a tracking expedition, showing you tantalising signs of the spoor of vanished or vanishing cultures (2006: 17, emphasis added).

15 Key features of the Bushman worldview, according to Guenther (1999: 13), are 'flexibility, adaptability and diversity, fluidity and amorphousness, ambivalence and ambiguity'. These attributes are suggested in the dense composition and layering of objects.

16 'Diptych' describes a two-part/panel work of art; 'triptych' three; tetraptych or quadriptych four; pentaptych five; hexaptych six; heptaptych seven; and octaptych eight.

17 Just as in the art of Qwaa Mangana which fuses 'traditional scenes' ('veld animals and plants, and leather-clad men and women out a-hunting and a-gathering, as well as other elements of traditional culture, including mystical and ecological ones') with 'modern scenes' ('horses and cattle, radios and guitars, jeans, shirts, belts or shoes, angels and peace doves') (Guenther 1997: 125).

18 These interpretations of Vetkat's work are not to be deemed in any sense exhaustive, but are only meant to open up a dialogue about the artist's oeuvre.

19 Guenther (2003) succinctly illustrates how Westerners tend to view contemporary San art from Botswana and Namibia as 'primordial' art when, in fact, such art challenges and decolonises those notions. Fortunately, the Eurocentrism behind notions of 'tribal' or 'primitive' art have been the subject of previous discussion and critical exposition (Anderson 1989; Guenther 1997; Price 2001). Guenther (1997: 121), in his study of the art of Qwaa Mangana, has bemoaned

the Western art critics and collector's inclination to treat such art as the anonymous, collective, cultural product of some iconic, primitive or primordialist "Other", cloaked with the mystique of pristinism, rather than of a living, breathing man or woman, with idiosyncrasies in style, vision, subject matter or aesthetic approach.

Ironically, despite bemoaning the Eurocentrism of art criticism which names non-Western art as 'tribal' or 'primitive', Guenther inexplicably persists in calling Bushman art 'tribal art' and Bushman artists such as Qwaa Mangana 'tribal artists'. Barnabas (2010) lucidly argues against attempts to see San art selectively as if it were not 'real' art. In particular, Barnabas questions the selective use of such art 'merely as a tool of development, a tourism endeavour and an income generator' (ibid: $<\mathrm{pg} \rightleftharpoons$ Fitting Bushman art into preselected categories continues the traditions of exhibition.

\section{References}

Adichie, C. 2009. The danger of a single story. http://www.ted.com/talks/chimamanda adichie the danger_of_a single_story (accessed

Aesop. n.d. Aesop's fables: 'The fox and the mask'. wwn Anderson, R.L. 1989. Art in small scale societies. Englewood Cliffs: Prentice Hall.

Bank, A. 2006. Bushmen in a Victorian world: the remarkable story of the Bleek-Lloyd collection of Bushman folklore. Cape Town: Double Storey.

Barnabas, S.B. 2010. Picking at the paint: viewing contemporary Bushman art as art. Visual Anthropology 23(5): 427-442. 
Barnard, A. Coat of arms and the body politic: Khoisan imagery and South African national identity. Ethnos 69(1): 5-22.

Beaumont P.B. and D. Morris. 1990. Guide to archaeological sites in the Northern Cape. Kimberley: McGregor Museum.

Brantlinger, P. 2003. Dark vanishings: discourse on the extinction of primitive races, 1800 1930. Ithaca, NY: Cornell University Press.

Brentjies, B. 1965. African rock art. London: JM Dent \& Sons Limited.

Conan Doyle, A. 1912. The lost world. London: Hodder and Stoughton.

Deacon, J. 1988. Rock engravings of the flat and grass Bushmen: some recent discoveries. In The state of the art: advances in world rock art research, ed. T.A. Dowson, <pages>. Johannesburg: University of Witwatersrand Rock Art Research Unit

Dickens, C. 1996[1884]. Great expectations. London: Penguin Classics.

Dowson, T.A., ed. 1988. The state of the art: advances in world rock art research. Johannesburg: University of Witwatersrand Rock Art Research Unit.

Dubow, S. 1995. Illicit union: scientific racism in modern South Africa. Cambridge: Cambridge University Press.

Eastwood, E. and C. Eastwood. 2006. Capturing the spoor: an exploration of southern African rock art. Claremont, SA: New Africa Books.

Elphick, R. 1977. Kraal and castle: the birth of South African society. New Haven: Yale University Press.

Fagg, W. and M. Plass. 1964. African sculpture. London: Dutton.

Gordon, R.J. 1985. Conserving Bushmen to extinction in southern Africa: the metaphysics of Bushman hating and empire building. In An end to laughter? Tribal peoples and economic development, ed. M. Colchester, 28-42. London: Survival International.

Gordon, R.J. 1993. The Bushman myth: the making of a Namibian underclass. Oxford: Westview Press.

Guenther, M.G. 1997. Lords of the desert land: politics and resistance of the Ghanzi Basarwa in the nineteenth century. Botswana Notes and Records 29(1): 121-140.

Guenther, M. 1997. 'Farm labourer, trance dancer, artist: the life and works of Qwaa Mangana.' Proceedings of Khoisan Identities and Cultural Heritage Conference, Cape Town, 12-16 July. Cape Town: InfoSource, pp. 121-134.

Guenther, M. 2003. Contemporary Bushman art, identity politics and the primitivism discourse. Anthropologica 45(1): 95-110.

Guenther, M.G. 1999. Tricksters and trancers: Bushman religion and society. Bloomington: Indiana University Press.

Hitchcock, R.K. 1985. Foragers on the move: San survival strategies in Botswana parks and reserves. Cultural Survival Quarterly 9(1): 31-36.

Jackson, S. and S. Robins. 1999. Miscast: the place of the museum in negotiating the Bushman past and present. Critical Arts 13(1): 69-101.

Kent, S., ed. 1996. Cultural diversity among twentieth-century foragers: an African perspective. Cambridge: Cambridge University Press.

Kruiper, V.R. 2011. Mooi loop: the sacred art of Vetkat Regopstaan Kruiper. Pretoria: Unisa Press (2014 edition). 


\section{Nyasha Mboti}

Lee, R.B. 2003. Indigenous rights and the politics of identity in post-apartheid South Africa. In At the risk of being heard: identity, indigenous rights and post-colonial states, ed. B. Dean and J.S. Levi, 80-111. Ann Arbor, Michigan: University of Michigan Press.

Lee, R.B and I. de Vore, eds. 1976. Kalahari hunter-gatherers: studies of the !Kung San and their neighbours. Massachusetts: Harvard University Press.

Lee, R.B. and R.K. Hitchcock. 2001. African hunter-gatherers: survival, history and the politics of identity. African Study Monographs Suppl. 26(1) : 257-280.

Lewis-Williams, D.J. and J. Clottes. 1998. The shamans of prehistory: trance magic and the painted caves. New York: Abrams.

Lewis-Williams, J.D. 1981a. Believing and seeing: symbolic meanings in southern Afric $<n$ ? $>$ paintings. London: Academic Press.

Lewis-Williams, J.D. 1981b. The thin red line: southern San notions and rock paintings of supernatural potency. South African Archaeological Bulletin 36(1): 5-13.

Lewis-Williams, J.D. 1983a. The rock art of southern Africa. Cambridge: Cambridge University Press.

Lewis-Williams, J.D 1983b. Science and rock art: introductory essay. South African Archaeological Society, Goodwin Series 4(1): 3-13.

Lewis-Williams, J.D. 1984. The empiricist impasse in southern African rock art studies. South African Archaeological Bulletin 39(1): 58-66.

Lewis-Williams, J.D. 2002. The mind in the cave: Consciousness and the origin of art. London: Thames and Hudson.

Lewis-Williams, J.D. and M. Biesele. 1978. Eland hunting rituals among Northern and Southern San groups: striking similarities. Africa 48(1): 117-134.

Marks, S. 1972. Khoisan resistance to the Dutch in the seventeenth and eighteenth centuries. Journal of African History 8(1): 55-80.

Mhiripiri, N. 2008. The tourist viewer, the Bushmen and the Zulu: imaging and (re)invention of identities through contemporary visual cultural productions. Ph.D. thesis, University of KwaZulu-Natal.

Mhiripiri, N. 2012. Re: Mooi loop republication. Email to the author, 17 November.

Miller, M. 1993. State of the peoples: a global human rights report on societies in danger. Boston: Beacon Press.

Morris, D. 1988. Engraved in place and time: a review of variability in the rock art of northern Cape and Karoo. South African Archaeological Bulletin 43(2): 109-121.

Morris, D. and P.B. Beaumont. 1991. !Nawabdanas: archaeological sites at Renosterkop, Kakama <Kakamas?> District, Northern Cape. South African Archaeological Bulletin 46(1): 115-124.

Parson, N. 2009. Clicko: the wild dancing Bushman. Chicago: University of Chicago Press.

Penn, N.G. 1996. 'Fated to perish': the destruction of the Cape San. In Miscast: negotiating the presence of the Bushmen, ed. P. Skotnes, 81-91. Cape Town: University of Cape Town Press.

Price, S. 2001. Primitive art in civilized places, $2^{\text {nd }}$ edition. Chicago: University of Chicago Press. 
Schoonraad, M., ed. 1971. Rock paintings of southern Africa. South African Association for the Advancement of Science, South Afriean Journal of Sen (speral issue): pares?

Skotnes, P. 1991. Is there life after trance? de arte 44(1): 16-24.

Skotnes, P. 1994. The visual as a site of meaning. In Contested images: Diversity in Southern African rock art research, ed. T.A. Dowson and D. Lewis-Williams, <pages>. Johannesburg: Witwatersrand University Press.

Skotnes, P., ed. 1996. Miscast: negotiating the presence of the Bushmen. Cape Town: University of Cape Town Press.

Skotnes, P. 2002. The politics of Bushman representations. In Images and empires: visuality in colonial and postcolonial Africa, ed. P.S. Landau and D.D. Kaspin, 253-274. California: University of California Press.

Smith, A., C. Malherbe, M. Guenther and P. Berens. 2000. The Bushmen of southern Africa: a foraging society in transition. Cape Town: David Philip.

Solomon, A. 1997. The myth of ritual origins? Ethnography, mythology and interpretation of San rock art. South African Archaeological Bulletin 52(1): 3-13.

Solomon, A. 2006. San spirituality and human evolution: Eight questions for Lewis-Williams and Pearce. South African Archaeological Bulletin 61(1): 209-212.

Solomon, A. 2009. Broken strings: interdisciplinarity and /Xam oral literature. Critical Arts 23(1): 26-41.

Sparks, A. 1997. The mind of South Africa: the story of the rise and fall of apartheid. London: Arrow Books.

Steel, R. 1988. Rock engravings of the Magaliesberg Valley. Johannesburg: Broederstroom Press.

Szalay, M. 1995. The San and the colonization of the Cape, 1770-1879: conflict, colonization and acculturation. Köln: R. Köppe.

Thornton, R.J. 1983. 'This dying out race': W.H.I. Bleek's approach to the languages of southern Africa. Social Dynamics 9(2): 1-10.

Tomaselli K.G., ed. 2007. Writing in the San/d: autoethnography among indigenous southern Africans. Lanham, MD: AltaMira.

Van der Post, L. 1977. The lost world of the Kalahari. London: Harvest/HBJ.

Volkman, T.A. 1985. Study guide: N!ai: the story of a !Kung woman. Watertown, Mass.: Documentary Educational Resources.

Wilmsen, E.N. 1989. Land filled with flies: a political economy of the Kalahari. Chicago: University of Chicago Press.

Wilmsen, E. 1995. First peoples? Images and imaginations in South African iconography. Critical Arts 9(2): 1-27.

Wright, J. 1971. Bushman raiders of the Drakensberg, 1840-1870. Pietermaritzburg: University of Natal Press.

\section{Films}

N!ai: the story of a !Kung woman. 1980. Dir. Jon Marshall. Documentary Educational Resources, 59 mins. 


\section{Nyasha Mboti}

The Gods must be Crazy. 1981. Dir. Jamie Uys. Ster Kinekor \& $20^{\text {th }}$ Century Fox, 109 mins. The Lost World. 1960. Dir. Irwin Allen. $20^{\text {th }}$ Century, 97mins.

Jurassic Park. 1993. Dir. Stephen Spielberg. Universal Pictures, 126 mins.

The Lost World: Jurassic Park. 1997. Dir. Stephen Spielberg. Universal Pictures, 129 mins.

The Simpsons S20/E13 'Gone Maggie Gone'. 2009. Dir. Chris Clements. Fox Broadcasting Corporation, 21 mins.

\section{Artworks}

Edvard Munch, The Scream. 1910. Oil, tempera, and pastel on cardboard, $91 \mathrm{~cm} \times 73.5 \mathrm{~cm}$. National Gallery, Oslo.

Pablo Picasso, Les Demoiselles d'Avignon (The Young Ladies of Avignon, originally titled The Brothel of Avignon). 1907. Oil on canvas, $243.9 \mathrm{~cm} \times 233.7 \mathrm{~cm}$. Museum of Modern Art, New York.

Pablo Picasso, Guernica. 1937. Oil on canvas, $349 \mathrm{~cm} \times 776 \mathrm{~cm}$. Museo Reina Sofia, Madrid.

Vincent van Gogh, The Potato Eaters. 1885 . Oil on canvas, $82 \mathrm{~cm} \times 114 \mathrm{~cm}$. Van Gogh Museum, Amsterdam. 